УДК 547.458:547.458.87:547.458.88

\title{
СТРУКТУРНО-ХИМИЧЕСКАЯ ХАРАКТЕРИСТИКА И БИОЛОГИЧЕСКАЯ АКТИВНОСТЬ ПОЛИСАХАРИДОВ HЕRACLEUM SOSNOWSKYI MANDEN
}

\author{
(C) Е.Г. Шахматов ${ }^{I}$, Е.А. Михайлова ${ }^{2}$, Е.Н. Макарова ${ }^{I^{*}}$ \\ ${ }^{1}$ Институт химии Коми научного центра УрО РАН, ул. Первомайская, 48, \\ Сыктывкар, 167982, Республика Коми (Россия), \\ e-mail: makarowa.elena-ma@ya.ru \\ ${ }^{2}$ Институт физиологии Коми научного центра УрО РАН, ул. Первомайская, \\ 50, Сыктывкар, 167982, Республика Коми (Россия)
}

Изучен характер изменения выхода и моносахаридного состава арабиногалактановых белков (AGP), пектиновых полисахаридов и связующих гликанов, выделенных из надземной части борщевика Сосновского Heracleum sosnowskyi экстракцией водой, раствором $\mathrm{HCl}$, раствором $\left(\mathrm{NH}_{4}\right)_{2} \mathrm{C}_{2} \mathrm{O}_{4}$, растворами $\mathrm{KOH}$ и $\mathrm{NaOH}$. Фракции, экстрагируемые водой, состояли, главным образом, из AGP и минорных количеств пектиновых полисахаридов. Фракции, экстрагируемые раствором $\mathrm{HCl}$, представляли собой смесь AGP и пектиновых полисахаридов, с преобладанием последних. Фракции, экстрагируемые раствором $\left(\mathrm{NH}_{4}\right)_{2} \mathrm{C}_{2} \mathrm{O}_{4}$, характеризовались значительным преобладанием пектиновых полисахаридов и минорным количеством AGP. При изучении моносахаридного состава фракций, экстрагируемых водным раствором $\mathrm{KOH}$, установлено, что главными компонентами их углеводных цепей являются остатки ксилозы, глюкозы и уроновых кислот что, вероятно, указывает на принадлежность данных фракций к связующим гликанам класса глюкуроноарабиноксиланов и ксилоглюканов. Главными компонентами углеводной цепи фракций, экстрагируемых водным раствором $\mathrm{NaOH}$, являются остатки маннозы и глюкозы, что, вероятно, указывает на принадлежность данных фракций к связующим гликанам класса глюкоманнанов. Последние две фракции также содержали некоторое количество пектиновых полисахаридов.

Показана высокая биологическая активность пектиновых полисахаридов, выделенных из надземной части борщевика Сосновского экстракцией раствором $\left(\mathrm{NH}_{4}\right)_{2} \mathrm{C}_{2} \mathrm{O}_{4}$, на всхожесть, энергию прорастания и рост проростков и корней Triticum aestivum L.

Ключевые слова: Heracleum sosnowskyi, пектин, арабиногалактановые белки, структура, биологическая активность полисахаридов.

Работа выполнена при финансовой поддержке проекта УрО РАН № 15-21-3-11; с использованием оборудования Центра коллективного пользования «Химия» Института химии Коми НЦ УрО РАН.

\section{Введение}

Многолетние исследования пектиновых полисахаридов и галактансодержащих полисахаридов, в т.ч. арабиногалактанов высших растений, показали, что они обладают широким спектром биологической и физиологической активности, что открывает широкие перспективы использования данных полисахаридов в медицине, ветеринарии, пищевой и косметической промышленности. Установлено, что биологическая и физиологическая активность вышеуказанных полисахаридов во многом определяется особенностями тонкой структуры их макромолекул, т.е. степенью полимеризации, составом, длиной и степенью разветвленности боковых углеводных цепей, наличием модифицирующих групп и характером их расположения, возможно, играющих определяющую, детерминирующую роль [1]. В связи с этим актуальным является ис-

Шахматов Евгений Геннадьевич - младший научный сотрудник, e-mail: shachmatow-eg@mail.ru Макарова Елена Николаевна - научный сотрудник, e-mail:makarowa.elena-ma@ya.ru

Михайлова Елена Андрияновна - научный сотрудник, e-mail: elena.elkina@mail.ru следование тонкого строения полисахаридов с целью обнаружения структурных элементов, влияющих на проявление ценных физико-химических свойств, а также физиологической и биологической активностью.

\footnotetext{
* Автор, с которым следует вести переписку.
} 
Борщевик Сосновского (Heracleum sosnowskyi Manden) - гигантский травянистый многолетник высотой 2 и более метров с мощным железисто опушенным полым стеблем и крупными перисторассеченными на 3-7 широколопастных долей листьями. В середине XX в. культивировался как силосное растение. Впоследствии выяснилось, что он легко дичает и проникает в естественные экосистемы. Дикорастущий вид борщевика Сосновского представляет несомненный интерес для исследования полисахаридных комплексов, которые он содержит, поскольку обладает огромной биомассой, быстро размножается, отличается богатым биохимическим составом. Показано, что экстракты, полученные из надземной части борщевика, обладают широким спектром физиологической активности, например иммуностимулирующим, сосудорасширяющим действием, применяются в качестве средства для лечения экзематозов и псориаза [2-5]. Также имеются сведения об изучении влияния препарата пектина борщевика в качестве регулятора роста для повышения продуктивности травянистых растений в условиях Севера. Показано, что обработка травостоев пектином из борщевика существенно повышает урожайность второго укоса [6].

Ранее было показано, что борщевик Сосновского содержит арабиногалактановые белки (AGP), а также является потенциальным источником пектиновых полисахаридов (содержание до 17\%) [7, 8].

Установлено, что линейная область главного по выходу полисахарида, экстрагируемого раствором $\left(\mathrm{NH}_{4}\right)_{2} \mathrm{C}_{2} \mathrm{O}_{4}$, представлена, главным образом, участками частично метилэтерифицированного гомогалактуронана (HG), а разветвленная область состоит из участков рамногалактуронана I (RG-I), кор которого представляет собой 1,2- $\alpha$-L-рамно-1,4- $\alpha$-D-галактуронан. Боковые углеводные цепи RG-I присоединены 1,4-гликозидной связью к остаткам $\alpha$-L-Rhap кора и образованы, главным образом, остатками терминальной $\beta$-D-Gal $p, 1,4$-связанной $\beta$-D-Gal $p$ и 1,6-связанной $\beta$-D-Gal $p$, указывающими на наличие $1,4-\beta-\mathrm{D}$ галактана [8].

Главная углеводная цепь AGP состоит из остатков 1,3 -связанной $\beta$-D-Gal $p$, боковые углеводные цепи разветвленной области образованы остатками 1,6-связанной $\beta$-D-Gal $p, 1,5$-связанной $\alpha$-L-Ara $f, 1,4$ связанной $\beta$-D-GlcA. Точками разветвления главной и боковых углеводных цепей являются остатки 3,6-ди$O$-замещенной $\beta$-D-Gal $p$. Остатки терминальных $\beta$-D-Gal $p, \alpha$-L-Ara $f$ и $\alpha$-L-Rha $p$ находятся на невосстанавливающих концах боковых цепей. Значительная часть $\beta-1,6$-галактана боковой цепи замещена остатками 4$O$-Me-GlcA с помощью $\beta$-( $1 \rightarrow 6)$-связи. Незначительная часть глюкуроновой кислоты входит в состав фрагмента: $\alpha$-Rhap-( $1 \rightarrow 4)-\beta$-GlcA- $\rightarrow$. Все фракции AGP содержали в дополнение к остаткам $\beta$-Dглюкуроновой кислоты остатки 1,4- $\alpha$-D-галактуроновой кислоты [7]. Эти результаты показывают, что некоторые AGP могут служить сшивающими агентами в клеточных стенках, связывая, по крайней мере, некоторые из пектиновых полисахаридов, тем самым обеспечивая возможность формирования непрерывной сети между полисахаридами и структурными белками.

Изучение структурных особенностей компонентов $H$. sosnowskyi и их химических характеристик может помочь разработать научные основы его переработки, что, в свою очередь, может способствовать решению проблемы по ограничению распространения и вредоносности борщевика как агрессивного инвазионного вида. При этом одним из основных методов борьбы является выкашивание для предотвращения цветения и созревания семян борщевика, что может быть совмещено с одновременной заготовкой надземной части борщевика для получения ценных продуктов. Кроме того, данные о химическом строении полисахаридов $H$. sosnowskyi могут быть использованы для выявления особенностей строения полисахаридов других травянистых растений.

Цель настоящей работы - выделение полисахаридов из надземной части $H$. sosnowskyi, общая химическая характеристика полученных полисахаридов и оценка их биологической активности.

\section{Экспериментальная часть}

Выделение полисахаридов из H. sosnowskyi. Надземную часть борщевика Сосновского (целые растения, включающие в себя листья, стебли и цветки) заготавливали в июле в период цветения растения. Сырье измельчали с помощью ножевой мельницы RM-120 (Россия) до размера частиц 10-15 мм и экстрагировали этиловым спиртом $\left(\mathrm{t} \sim 55^{\circ} \mathrm{C}\right)$ дважды по 2 ч для удаления низкомолекулярных веществ. Остаток сырья сушили на воздухе, выход воздушно-сухого остатка составил $~ 9 \%$ от исходного свежего сырья.

На первой ступени полученное обезжиренное воздушно-сухое сырье (25 г) экстрагировали водой (здесь и далее по 0,5 л экстрагента) при перемешивании и $\mathrm{t} \sim 70-71{ }^{\circ} \mathrm{C}$ в течение 2 ч. Применяли пятикратную экстракцию. Фракции с каждой экстракции собирали отдельно, центрифугировали, концентрировали, 
осаждали полисахариды спиртом (1 : 3 по объему); полученный осадок отделяли, растворяли, диализовали и лиофильно высушивали. Получили набор пяти фракций полисахаридов: $\mathrm{HS}_{\mathrm{W}}-\mathrm{I}, \mathrm{HS}_{\mathrm{w}}-\mathrm{II}, \mathrm{HS}_{\mathrm{w}}$-III, $\mathrm{HS}_{\mathrm{W}}$-IV, $\mathrm{HS}_{\mathrm{W}}-\mathrm{V}$, с выходом $139,53,55,22,36$ мг соответственно.

На второй ступени остаток сырья экстрагировали водой, подкисленной $\mathrm{HCl}$ до $\mathrm{pH} \sim 3,5-4$, при перемешивании и $\mathrm{t} \sim 70-71{ }^{\circ} \mathrm{C}$ в течение 2 ч. Применяли пятикратную экстракцию. Полученные экстракты обрабатывали, как описано выше. Получили набор четырех фракций полисахаридов $\mathrm{HS}_{\mathrm{A}}-\mathrm{I}, \mathrm{HS}_{\mathrm{A}}-\mathrm{II}, \mathrm{HS}_{\mathrm{A}}-\mathrm{III}$, $\mathrm{HS}_{\mathrm{A}}$-IV, с выходом 56, 56, 80, 152 мг соответственно. Фракция $\mathrm{HS}_{\mathrm{A}}-\mathrm{V}$ (выход $\sim 150$ мг) была испорчена.

На третьей ступени остаток сырья экстрагировали $0,7 \%$ водным раствором $\left(\mathrm{NH}_{4}\right)_{2} \mathrm{C}_{2} \mathrm{O}_{4}$, применяли пятикратную экстракцию при перемешивании и $\mathrm{t} \sim 70-71{ }^{\circ} \mathrm{C}$ в течение 2 ч. Полученные экстракты обраба-

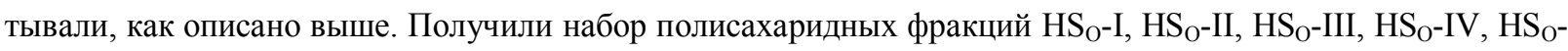
$\mathrm{V}$, с выходом 3110, 663, 252, 115, 123 мг соответственно.

На четвертой ступени остаток сырья экстрагировали водным раствором 7,0\% КОН (содержащим 10 $\mathrm{мM} / л \mathrm{NaBH}_{4}$ ), применяли пятикратную экстракцию по 2 ч при перемешивании и комнатной температуре. Полученные экстракты охлаждали, подкисляли уксусной кислотой до $\mathrm{pH}$ 5,0 и центрифугировали, далее растворы концентрировали, диализовали и лиофильно высушивали. Получили набор полисахаридных фракций $\mathrm{HS}_{\mathrm{K}}-\mathrm{I}, \mathrm{HS}_{\mathrm{K}}-\mathrm{II}, \mathrm{HS}_{\mathrm{K}}-\mathrm{III}, \mathrm{HS}_{\mathrm{K}}-\mathrm{IV}, \mathrm{HS}_{\mathrm{K}}-\mathrm{V}$ с выходом 704, 305, 393, 144, 103 мг соответственно.

На пятой ступени остаток сырья экстрагировали $14 \%$ водным раствором $\mathrm{NaOH}$ и $4 \% \mathrm{H}_{3} \mathrm{BO}_{3}$, содержащим $10 \mathrm{MM} / л \mathrm{NaBH}_{4}$, применяли пятикратную экстракцию по 2 ч при перемешивании и комнатной температуре. Полученные экстракты обрабатывали, как описано выше. Получили набор полисахаридных фракций $\mathrm{HS}_{\mathrm{N}}-\mathrm{I}, \mathrm{HS}_{\mathrm{N}}-\mathrm{II}, \mathrm{HS}_{\mathrm{N}}-\mathrm{III}, \mathrm{HS}_{\mathrm{N}}-\mathrm{IV}, \mathrm{HS}_{\mathrm{N}}-\mathrm{V}$ с выходом 952, 69, 95, 26, 40 мг, соответственно.

Общие экспериментальные условия. Содержание углеводов определяли реакцией с фенолом в присутствии конц. $\mathrm{H}_{2} \mathrm{SO}_{4}$ [9]. Содержание гликуроновых кислот определяли по реакции с 3,5-диметилфенолом в присутствии концентрированной серной кислоты (калибровочный график построен для D-галактуроновой кислоты (Sigma-Aldrich), фотоколориметрирование проводили при двух длинах волн: 400 и 450 нм) [10]; содержание белка - по методу Бредфорд (калибровочный график построен для бычьего сывороточного альбумина, фотоколориметрирование проводили при 595 нм) [11]. Все измерения проводили в трех аналитических повторностях и для расчетов использовали средние значения.

Спектрофотометрические измерения проводили на приборе Shimadzu UV-1700 (PharmaSpec).

Для определения качественного и количественного моносахаридного состава полученных полисахаридов проводили полный кислотный гидролиз. К навеске (2-5 мг) исследуемого образца добавляли 1 мл $2 \mathrm{M} \mathrm{CF}_{3} \mathrm{COOH}$, содержащего мио-инозит $\left(0,5-1,0\right.$ мг/мл). Смесь термостатировали в течение 5 ч при $100{ }^{\circ} \mathrm{C}$. Избыток кислоты удаляли многократным упариванием гидролизата досуха с $\mathrm{CH}_{3} \mathrm{OH}$. Нейтральные моносахариды идентифицировали методом ГЖХ в виде соответствующих ацетатов полиолов [12]. ГЖХ выполняли на хроматографе Shimadzu GC-2010AF с пламенно-ионизационным детектором и интегратором HP-1 на капиллярной колонке Agilent, 30 м $\times 0.25$ мм, газ-носитель - Не, в программе: от $175^{\circ} \mathrm{C}(1$ мин) до $250{ }^{\circ} \mathrm{C}$ (2 мин) со скоростью $3^{\circ}$ мин. Процентное содержание моносахаридов от суммарного содержания препарата вычисляли из площадей пиков, используя коэффициенты отклика детектора.

Водные растворы концентрировали на ротационном испарителе (Неidolph, Германия) в вакууме при $40-45^{\circ} \mathrm{C}$, центрифугировали на приборе Sigma (Германия) при 5000-10,000 g в течение 10-20 мин, образцы лиофилизовали на приборе Christ Alpha 2-4 LD (Nikolab, Германия) с постоянным вакуумом $<10$ mТorr при $-65^{\circ} \mathrm{C}$.

Определение биологической активности полисахаридов из Heracleum sosnowskyi. Для определения действия полисахаридов из борщевика Сосновского на ранние стадии онтогенеза злаков использовали семена пшеницы мягкой Triticum aestivum L. сорта «Иргина». Семена перед посевом обрабатывали $0,002 \%$ водными растворами полисахаридов. Контролем служили семена, которые предварительно обрабатывали водопроводной водой. Обработанные семена инкубировали в чашках Петри в течение 8 сут. при $23{ }^{\circ} \mathrm{C}$. Всхожесть семян определяли в процентах. Для подсчета энергии прорастания через 2 и 8 сут. считали нормально проросшие семена, непроросшие и ненормально проросшие семена и подсчитывали долю нормально проросших семян от их общего количества. В процессе прорастания семян и роста проростков на 2 , 4, 6 и 8-е сутки измеряли длину корней и проростков пшеницы. Опыты проводили в четырехкратной повторности по 50 семян в каждом варианте опыта. Достоверность результатов оценивали с помощью tкритерия Стьюдента, для статической обработки использовали компьютерную программу ORIGIN 4.1. В таблице представлены среднестатистические значения параметров и их стандартные ошибки. 


\section{Обсуждение результатов}

Последовательным экстрагированием надземной части борщевика Сосновского водой, водой, подкисленной до $\mathrm{pH} \sim 3,5-4$, раствором оксалата аммония, растворами гидроксида калия и гидроксида натрия получили набор фракций полисахаридов: $\mathrm{HS}_{\mathrm{W}}-\mathrm{I}-\mathrm{HS}_{\mathrm{W}^{-}}-\mathrm{V}, \mathrm{HS}_{\mathrm{A}}-\mathrm{I}-\mathrm{HS}_{\mathrm{A}}-\mathrm{IV}, \mathrm{HS}_{\mathrm{O}^{-}} \mathrm{I}-\mathrm{HS}_{\mathrm{O}^{-}}-\mathrm{V}, \mathrm{HS}_{\mathrm{K}}-\mathrm{I}-\mathrm{HS}_{\mathrm{K}}-\mathrm{V}$ и $\mathrm{HS}_{\mathrm{N}} \mathrm{I}-\mathrm{HS}_{\mathrm{N}} \mathrm{V}$ соответственно (табл. 1). Показано, что главными полисахаридами, выделенными из надземной части борщевика Сосновского, являются пектиновые полисахариды $\mathrm{HS}_{\mathrm{O}}$, экстрагируемые оксалатом аммония, при этом максимальный выход наблюдается для первой экстракции и составляет 12,5\%, суммарный выход пектинов составляет $\sim 17 \%$ от массы возд.-сух. обезжиренного сырья (табл. 1 ).

Следует отметить, что при последовательной экстракции водой, раствором оксалата аммония, растворами гидроксида калия и гидроксида натрия наблюдается снижение выхода фракций от I к V, тогда как для фракций, экстрагируемых водным раствором $\mathrm{HCl}$, наблюдается обратное явление. Наблюдаемое увеличение выхода полимеров (табл. 1) при экстракции водным раствором $\mathrm{HCl}$, вероятно, можно объяснить постепенным разрушением надмолекулярной комплексной структуры, что позволяет извлечь Са ${ }^{2+}$ связанные пектиновые полисахариды.

Моносахаридный анализ фракций $\mathrm{HS}_{\mathrm{W}}-\mathrm{I}-\mathrm{HS}_{\mathrm{W}}-\mathrm{V}$ выявил высокое содержание остатков D-гликуроновых кислот, D-галактозы (до 37\%) и L-aрабинозы (до 5,6\%) - характерных компонентов пектиновых полисахаридов и арабиногалактана типа II, присутствующего часто в виде арабиногалактановых белков (табл. 1). Из представленных результатов видно, что при последовательной экстракции увеличивается содержание гликуроновых кислот от 23 до 59\% (табл. 1).

При анализе моносахаридного состава фракций $\mathrm{HS}_{\mathrm{A}}-\mathrm{I}-\mathrm{HS}_{\mathrm{A}}-\mathrm{IV}$ установлено, что они имеют близкое содержание нейтральных моносахаридов и гликуроновых кислот как между собой, так и в сравнении с фракциями $\mathrm{HS}_{\mathrm{W}}-\mathrm{IV}$ и $\mathrm{HS}_{\mathrm{W}}-\mathrm{V}$ (табл. 1).

В предыдущих работах методами ионообменной хроматографии, частичного кислотного и ферментативного гидролизов, одномерной и двумерной ЯМР спектроскопии было установлено, что фракции $\mathrm{HS}_{\mathrm{W}} \mathrm{I}-$ $\mathrm{HS}_{\mathrm{W}}$-III состояли, главным образом, из AGP и минорных количеств пектиновых полисахаридов; фракции $\mathrm{HS}_{\mathrm{W}}-\mathrm{IV}, \mathrm{HS}_{\mathrm{W}}-\mathrm{V}$ и $\mathrm{HS}_{\mathrm{A}}-\mathrm{I}-\mathrm{HS}_{\mathrm{A}}$-VI представляли собой смесь AGP и пектиновых полисахаридов, с преобладанием последних [7,8].

При анализе моносахаридного состава полисахаридных фракций $\mathrm{HS}_{\mathrm{O}}-\mathrm{I}-\mathrm{HS}_{\mathrm{O}}-\mathrm{V}$ установлено высокое содержание остатков гликуроновых кислот, рамнозы, галактозы и арабинозы, характерных компонентов главной и боковых углеводных цепей пектиновых полисахаридов. Из представленных результатов видно, что при последовательной экстракции содержание гликуроновых кислот уменьшается от 83 до $51 \%$ (табл. 1). Показано, что фракции $\mathrm{HS}_{\mathrm{O}}-\mathrm{I}-\mathrm{HS}_{\mathrm{O}}-\mathrm{V}$ характеризуются значительным преобладанием пектиновых полисахаридов и минорным количеством AGP $[7,8]$.

Таким образом, при последовательной экстракции Heracleum водой, раствором $\mathrm{HCl}$ (pH 4) и раствором $\left(\mathrm{NH}_{4}\right)_{2} \mathrm{C}_{2} \mathrm{O}_{4}$ наблюдается уменьшение содержания AGP и увеличение содержания пектиновых полисахаридов.

Экстракция связующих гликанов водными растворами щелочей позволяет, используя различную растворяющую способность водных растворов гидроксидов калия и натрия при разных концентрациях, фракционировать полисахариды на группы. Так, растворы КОН применяют для выделения легкорастворимых 4-O-метилглюкуроноксиланов, не вызывая при этом солюбилизации менее растворимых глюкоманнанов. Последние переходят в раствор под воздействием растворов $\mathrm{NaOH}$ относительно высокой концентрации (как правило, 15-18\%). При этом добавление борной кислоты к щелочному раствору повышает его растворяющую способность по отношению к маннанам [13].

При последовательной экстракции надземной части борщевика водным раствором гидроксида калия получили пять полисахаридных фракций $\mathrm{HS}_{\mathrm{K}}-\mathrm{I}-\mathrm{HS}_{\mathrm{K}}-\mathrm{V}$. При изучении моносахаридного состава этих фракций установлено, что главными компонентами их углеводных цепей являются остатки ксилозы, глюкозы и гликуроновых кислот, что, вероятно, указывает на принадлежность данных фракций к связующим гликанам класса глюкуроноарабиноксиланов (табл. 1). Показано, что при последовательной экстракции содержание остатков ксилозы и гликуроновых кислот снижается от 32,2 до 13,8\% и от 17,1 до 10,8\%, соответственно, а содержание остатков глюкозы, напротив, увеличивается от 9,5 до 16,1\%. Учитывая высокое содержание остатков Glc, можно предположить, что некоторая часть связующих гликанов представлена ксилоглюканами. Известно, что остов молекулы ксилоглюкана представляет собой $\beta$-D-( $1 \rightarrow 4)$-глюкан, к которому присоединены по С-6 атомам остатки ксилозы, в то время как остов молекулы арабиноглюкуроноксилана представляет собой $\beta$-D-( $1 \rightarrow 4)$-ксилан, который может быть замещен по C-2 или C-3 атомам остатками арабинозы и глюкуроновой кислоты $[14,15]$. 
Таблица 1. Выход и состав фракций Heracleum $(\%$ w/w)

\begin{tabular}{|c|c|c|c|c|c|c|c|c|c|}
\hline \multirow{2}{*}{ Фракции } & \multirow{2}{*}{$\begin{array}{c}\text { Выход }^{*}, \\
\%\end{array}$} & \multirow{2}{*}{ GliA } & \multicolumn{6}{|c|}{ Нейтральные моносахариды } & \multirow{2}{*}{ Белок } \\
\hline & & & Gal & Ara & Rha & Xyl & Glc & Man & \\
\hline $\mathrm{HS}_{\mathrm{W}}-\mathrm{I}$ & 0,6 & 23,0 & 36,6 & 5,6 & 2,1 & 0,2 & 2,3 & 1,3 & 8,5 \\
\hline $\mathrm{HS}_{\mathrm{W}}-\mathrm{II}$ & 0,2 & 35,0 & 16,3 & 3,2 & 3,7 & 1,5 & 4,0 & 1,4 & 9,1 \\
\hline $\mathrm{HS}_{\mathrm{W}}$-III & 0,2 & 40,0 & 17,0 & 4,6 & 3,8 & 0,7 & 5,1 & 1,4 & 8,5 \\
\hline $\mathrm{HS}_{\mathrm{W}}-\mathrm{IV}$ & 0,1 & 58,7 & 16,6 & 5,1 & 3,7 & 1,7 & 5,2 & 0,9 & 8,1 \\
\hline $\mathrm{HS}_{\mathrm{W}}-\mathrm{V}$ & 0,1 & 57,0 & 17,4 & 4,9 & 3,6 & 1,7 & 8,2 & 0,6 & 6,6 \\
\hline $\mathrm{HS}_{\mathrm{A}}-\mathrm{I}$ & 0,2 & 49,7 & 14,2 & 8,2 & 2,3 & 3,1 & 3,0 & 0,6 & 5,7 \\
\hline $\mathrm{HS}_{\mathrm{A}}-\mathrm{II}$ & 0,2 & 51,8 & 17,6 & 6,6 & 2,0 & 0,8 & 2,0 & 0,4 & 5,5 \\
\hline $\mathrm{HS}_{\mathrm{A}}$-III & 0,3 & 52,5 & 16,9 & 9,2 & 2,6 & 0,8 & 2,5 & 0,3 & 5,4 \\
\hline $\mathrm{HS}_{\mathrm{A}}-\mathrm{IV}$ & 0,6 & 60,0 & 15,5 & 6,8 & 3,0 & 3,1 & 4,3 & 0,2 & 5,6 \\
\hline $\mathrm{HS}_{\mathrm{O}-\mathrm{I}}$ & 12,5 & 83,0 & 4,7 & 2,6 & 3,7 & 0,6 & 2,6 & 0,5 & 2,0 \\
\hline $\mathrm{HS}_{\mathrm{O}}-\mathrm{II}$ & 2,7 & 80,0 & 5,1 & 4,2 & 3,7 & 0,7 & 2,6 & 0,2 & 3,2 \\
\hline $\mathrm{HS}_{\mathrm{O}}-\mathrm{III}$ & 1,0 & 77,3 & 4,5 & 4,8 & 3,4 & 0,7 & 2,0 & 0,1 & 3,7 \\
\hline $\mathrm{HS}_{\mathrm{O}}-\mathrm{IV}$ & 0,5 & 51,3 & 11,7 & 5,3 & 5,4 & 2,1 & 10,0 & 0,3 & 3,5 \\
\hline $\mathrm{HS}_{\mathrm{O}^{-}} \mathrm{V}$ & 0,5 & 57,4 & 4,9 & 1,8 & 2,2 & 0,6 & 3,2 & 0,1 & 3,0 \\
\hline $\mathrm{HS}_{\mathrm{K}^{-}} \mathrm{I}$ & 2,8 & 17,1 & 4,5 & 2,4 & 0,8 & 32,2 & 9,5 & 1,3 & 8,4 \\
\hline $\mathrm{HS}_{\mathrm{K}}-\mathrm{II}$ & 1,2 & 14,1 & 4,6 & 2,2 & 0,8 & 23,0 & 12,4 & 2,1 & 15,3 \\
\hline $\mathrm{HS}_{\mathrm{K}}-\mathrm{III}$ & 1,6 & 12,6 & 4,7 & 2,1 & 0,7 & 21,4 & 15,0 & 1,9 & 14,7 \\
\hline $\mathrm{HS}_{\mathrm{K}}-\mathrm{IV}$ & 0,6 & 10,9 & 4,4 & 2,5 & 0,9 & 13,9 & 16,1 & 3,7 & 18,4 \\
\hline $\mathrm{HS}_{\mathrm{K}}-\mathrm{V}$ & 0,4 & 10,8 & 5,8 & 3,1 & 1,1 & 13,8 & 13,9 & 4,9 & 19,2 \\
\hline $\mathrm{HS}_{\mathrm{N}}-\mathrm{I}$ & 3,8 & 15,4 & 4,7 & 1,9 & 0,2 & 5,5 & 10,7 & 14,4 & 12,6 \\
\hline $\mathrm{HS}_{\mathrm{N}^{-}} \mathrm{II}$ & 0,3 & 14,0 & 6,2 & 3,2 & 1,4 & 11,1 & 23,4 & 21,4 & 18,0 \\
\hline $\mathrm{HS}_{\mathrm{N}}-\mathrm{III}$ & 0,4 & 12,6 & 4,3 & 3,3 & 1,5 & 7,1 & 13,4 & 7,7 & 14,7 \\
\hline $\mathrm{HS}_{\mathrm{N}}-\mathrm{IV}$ & 0,1 & 15,3 & 6,2 & 4,3 & 2,5 & 8,4 & 13,2 & 3,7 & 15,6 \\
\hline $\mathrm{HS}_{\mathrm{N}^{-}} \mathrm{V}$ & 0,2 & 16,8 & 7,2 & 5,5 & 3,3 & 10,0 & 17,3 & 3,1 & 19,7 \\
\hline
\end{tabular}

* Выходы фракций оценивали в процентах от массы воздушно-сухого обезжиренного растительного материала; GliA гликуроновые кислоты.

При последовательной экстракции надземной части Heracleum водным раствором гидроксида натрия получили пять полисахаридных фракций $\mathrm{HS}_{\mathrm{N}}-\mathrm{I}-\mathrm{HS}_{\mathrm{N}}-\mathrm{V}$. Главными компонентами их углеводной цепи являются остатки маннозы и глюкозы, что, вероятно, указывает на принадлежность данных фракций к связующим гликанам класса глюкоманнанов (табл. 1).

Моносахаридный анализ фракций $\mathrm{HS}_{\mathrm{K}}-\mathrm{I}-\mathrm{HS}_{\mathrm{K}}-\mathrm{V}$ и $\mathrm{HS}_{\mathrm{N}}-\mathrm{I}-\mathrm{HS}_{\mathrm{N}}-\mathrm{V}$ указывает на наличие в них нескольких классов полисахаридов, поскольку, кроме вышеуказанных остатков, они содержат также остатки арабинозы, галактозы и рамнозы, типичные для пектиновых полисахаридов, которые, вероятно, запутались в целлюлозной матрице. Это согласуется с предыдущими исследованиями, показывающими, что фракции, экстрагируемые щелочами, часто содержат значительное количество пектиновых полисахаридов [16, 17].

Установленные изменения выхода и состава полисахаридных фракций в процессе экстракции Heracleum позволяют целенаправленно получать полисахариды с желаемым составом и выходом для последующего изучения либо практического применения.

Таким образом, экстракция зеленой массы борщевика Сосновского экстрагентами различной силы привела к получению сложной смеси полисахаридов. При этом молекулы одних и тех же полисахаридов были обнаружены нами в различных фракциях, отличающихся между собой по моносахаридному составу и преобладающим типам полисахаридов.

Для исследования биологической активности полисахаридов, выделенных из надземной части $H$. sosnowskyi, было изучено влияние фракций: $\mathrm{HS}_{\mathrm{W}}$-I, которая содержала, главным образом, свободные AGP; $\mathrm{HS}_{\mathrm{W}}$-III, которая состояла, главным образом, из AGP и пектиновых полисахаридов; $\mathrm{HS}_{\mathrm{W}}-\mathrm{V}$ и $\mathrm{HS}_{\mathrm{A}}-\mathrm{I}$, представляющих собой смесь AGP и пектиновых полисахаридов, с преобладанием последних; $\mathrm{HS}_{\mathrm{O}}-\mathrm{I}$ и $\mathrm{HS}_{\mathrm{O}}-\mathrm{III}$, характеризующихся значительным преобладанием пектиновых полисахаридов и минорным количеством $\mathrm{AGP} ; \mathrm{HS}_{\mathrm{K}}-\mathrm{I}$ и $\mathrm{HS}_{\mathrm{N}}-\mathrm{I}$, содержащих, главным образом, связующие гликаны класса глюкуроноарабиноксиланов и глюкоманнанов.

Оценивали влияние выделенных полисахаридов на рост проростков по следующим показателям: энергия прорастания, всхожесть, длина корня и длина проростка на 2, 4, 6 и 8-е сутки, при этом использовали сравнение скорости прорастания семян и роста опытных и контрольных растений. 
Из представленных результатов видно, что практически все испытуемые полисахариды оказывают ростостимулирующее влияние на всхожесть и скорость прорастания семян, рост проростков и корней пшеницы (табл. 2). Наибольшее ростостимулирующее влияние оказывают фракции $\mathrm{HS}_{\mathrm{O}}-\mathrm{I}$ и $\mathrm{HS}_{\mathrm{O}}$-III, главная углеводная цепь которых представлена, главным образом, участками частично метилэтерифицированного гомогалактуронана и небольшими участками рамногалактуронана I, боковые углеводные цепи которого представлены преимущественно 1,4- $\beta$-D-галактаном. Они повышают всхожесть на 30\% по сравнению с контролем. У семян, обработанных растворами данных полисахаридов, проростки появляются уже на вторые сутки после начала инкубации (табл. 2). Скорость роста проростков пшеницы при обработке семян растворами полисахаридов $\mathrm{HS}_{\mathrm{O}}-\mathrm{I}$ и $\mathrm{HS}_{\mathrm{O}} \mathrm{IV}$ выше в среднем в два раза по сравнению с контролем. Максимальный эффект их действия на рост проростков пшеницы наблюдается со 2-х по 6-е сутки проращивания семян. Скорость роста корневой системы пшеницы при обработке растворами данных полисахаридов также выше в среднем в 2 раза по сравнению с контролем (табл. 2).

Энергию прорастания определяли по количеству, весу и длине проростков. Все испытуемые полисахариды увеличивают энергию прорастания. У семян, обработанных полисахаридами $\mathrm{HS}_{\mathrm{O}}-\mathrm{I}$ и $\mathrm{HS}_{\mathrm{O}}-\mathrm{III}$, энергия прорастания выше в среднем в 1,6 раза по сравнению с контролем.

Таким образом, из всех испытуемых полисахаридов наибольшее ростостимулирующее влияние на всхожесть и скорость прорастания семян, рост проростков и корней Triticum aestivum L. сорта «Иргина» оказывает полисахарид, содержащий, главным образом, участки частично метилэтерифицированного $\alpha$ 1,4-D-галактопиранозилуронана.

Следует отметить, что аналогичные результаты были получены при обработке семян злаковых культур: пшеницы мягкой Triticum aestivum L. сорта «Иргина», овса Avena sativa L. сорта «Кировский» и ржи посевной Secale cereale L. сорта «Фаленская» растворами полисахаридов, выделенных из древесной зелени пихты (Abies sibirica Ledeb.) и плодов граната (Punica granatum L.), было установлено, что наибольшей биологической активностью в отношении влияния на всхожесть, энергию прорастания и скорость роста проростков и корней вышеуказанных злаковых культур обладают фракции пектиновых полисахаридов, характеризующиеся высоким содержанием GalA, т.e. содержащие значительные участки $\alpha-1,4-\mathrm{D}-$ галактуронана [18, 19].

Интересно отметить, что при обработке семян растворами фракций $\mathrm{HS}_{\mathrm{W}}-\mathrm{I}, \mathrm{HS}_{\mathrm{W}}-\mathrm{III}, \mathrm{HS}_{\mathrm{W}}$-V наибольшее ростостимулирующее влияние проявляет фракция $\mathrm{HS}_{\mathrm{W}}-\mathrm{I}$, содержащая, главным образом, свободные AGP, максимальный эффект действия которой наблюдается с 4-х по 6-е сутки проращивания семян, однако к 8-м суткам эксперимента длина корня и проростка практически сравнивается с длиной корня и проростка семян, обработанных полисахаридами $\mathrm{HS}_{\mathrm{W}}$-III и $\mathrm{HS}_{\mathrm{W}}-\mathrm{V}$. Таким образом, полученные полисахариды, даже будучи близкими по составу, различаются по биологической активности за счет различий в тонкой структуре.

Для того чтобы найти реальные корреляции между структурными особенностями и биологическими свойствами этих сложных полимеров, необходимо дальнейшее накопление информации о взаимосвязи структуры изучаемых полисахаридов и проявляемой ими биологической активности.

Таблица 2. Влияние полисахаридных фракций, выделенных из борщевика Сосновского, на всхожесть, энергию прорастания, рост корней и проростков пшеницы мягкой Triticum aestivum L. copта «Иргина»

\begin{tabular}{|c|c|c|c|c|c|c|c|c|c|c|c|c|c|c|}
\hline \multirow[t]{2}{*}{ Фракция } & \multicolumn{4}{|c|}{ Всхожесть, \% } & \multicolumn{2}{|c|}{ ЭП*, \% } & \multicolumn{4}{|c|}{ Длина корня, мм } & \multicolumn{4}{|c|}{ Длина проростка, мм } \\
\hline & 2 сут. & 4 сут. & 6 сут. & 8 сут. & 2 сут. & 8 сут. & 2 сут. & 4 сут. & 6 сут. & 8 сут. & 2 сут. & 4 сут. & 6 сут. & 8 сут. \\
\hline Контроль & 43 & 51 & 57 & 67 & 17 & 49 & $7 \pm 4$ & $16 \pm 5$ & $22 \pm 6$ & $30 \pm 9$ & - & $8 \pm 3$ & $15 \pm 5$ & $22 \pm 7$ \\
\hline $\mathrm{HS}_{\mathrm{W}}-\mathrm{I}$ & 45 & 53 & 62 & 77 & 23 & 64 & $7 \pm 4$ & $23 \pm 5$ & $33 \pm 6$ & $42 \pm 7$ & - & $14 \pm 4$ & $25 \pm 7$ & $30 \pm 7$ \\
\hline $\mathrm{HS}_{\mathrm{W}}$-III & 40 & 48 & 56 & 76 & 16 & 60 & $6 \pm 3$ & $15 \pm 4$ & $23 \pm 5$ & $38 \pm 7$ & - & $9 \pm 3$ & $14 \pm 4$ & $32 \pm 9$ \\
\hline $\mathrm{HS}_{\mathrm{W}}-\mathrm{V}$ & 41 & 52 & 62 & 75 & 22 & 56 & $7 \pm 5$ & $16 \pm 5$ & $28 \pm 5$ & $38 \pm 9$ & - & $9 \pm 3$ & $19 \pm 6$ & $28 \pm 7$ \\
\hline $\mathrm{HS}_{\mathrm{A}}-\mathrm{I}$ & 44 & 50 & 65 & 74 & 18 & 60 & $7 \pm 5$ & $15 \pm 5$ & $31 \pm 6$ & $45 \pm 8$ & - & $6 \pm 2$ & $24 \pm 6$ & $35 \pm 8$ \\
\hline $\mathrm{HS}_{\mathrm{O}}-\mathrm{I}$ & 48 & 61 & 72 & 86 & 26 & 76 & $9 \pm 5$ & $27 \pm 5$ & $44 \pm 9$ & $64 \pm 12$ & $2 \pm 1$ & $18 \pm 5$ & $36 \pm 7$ & $42 \pm 11$ \\
\hline $\mathrm{HS}_{\mathrm{O}}-\mathrm{III}$ & 48 & 60 & 70 & 87 & 28 & 77 & $10 \pm 4$ & $29 \pm 5$ & $42 \pm 7$ & $59 \pm 7$ & $3 \pm 2$ & $19 \pm 4$ & $34 \pm 4$ & $44 \pm 8$ \\
\hline $\mathrm{HS}_{\mathrm{K}}-\mathrm{I}$ & 44 & 57 & 64 & 76 & 23 & 69 & $7 \pm 4$ & $25 \pm 5$ & $35 \pm 5$ & $38 \pm 8$ & - & $15 \pm 3$ & $19 \pm 5$ & $26 \pm 8$ \\
\hline $\mathrm{HS}_{\mathrm{N}}-\mathrm{I}$ & 45 & 55 & 63 & 73 & 20 & 56 & $7 \pm 4$ & $20 \pm 5$ & $28 \pm 6$ & $40 \pm 7$ & - & $10 \pm 4$ & $25 \pm 7$ & $31 \pm 7$ \\
\hline
\end{tabular}

* ЭП - энергия прорастания 


\section{Выводы}

На основании полученных результатов можно сделать следующие выводы: из надземной части борщевика Сосновского H. sosnowskyi выделены арабиногалактановые белки, пектиновые полисахариды, а также связующие гликаны, в состав которых входят глюкуроноксилан, ксилоглюкан и глюкоманнан. Дана структурно-химическая характеристика выделенных полисахаридов и определена их биологическая активность. Показано, что борщевик Сосновского может быть потенциальным источником пектиновых полисахаридов (выход $\sim 17 \%$ от возд.-сух. обезжиренного сырья). Установленные изменения выхода и состава полисахаридных фракций в процессе экстракции Heracleum позволяют целенаправленно получать полисахариды с желаемым составом и выходом для последующего изучения либо практического применения.

Наибольшей биологической активностью в отношении влияния на всхожесть, энергию прорастания и скорость роста побегов и корней Triticum aestivum L. сорта «Иргина» обладают фракции пектинов, выделенные из H. sosnowskyi экстракцией оксалатом аммония, содержащие, главным образом, участки частично метилэтерифицированного гомогалактуронана и неболышие участки рамногалактуронана I. Данные по биологической активности указывают на перспективность использования надземной части борщевика Сосновского как источника биологически активных веществ, обладающих ростстимулирующим действием.

\section{Сиисок литературы}

1. Медведева Е.Н., Бабкин В.А., Остроухова Л.А. Арабиногалактан лиственницы - свойства и перспективы использования // Химия растительного сырья. 2003. №1. С. 27-27.

2. Kumar, S., Gupta, P., Sharma, S., Kumar, D. A review on immunostimulatory plants // J. of Chin. Integrative Medicine. 2011. Vol. 9. Pp. 117-128.

3. Senejoux, F., Demougeot, C., Cuciureanu, M., Miron, A., Cuciureanu, R., Berthelot, A., et al. Vasorelaxant effects and mechanisms of action of Heracleum sphondylium L. (Apiaceae) in rat thoracic aorta // J. Ethnopharmacol. 2013. Vol. 147. Pp. 536-539.

4. Патент 2057541 (RU). Средство для лечения экзематозов / А.И. Суханов. 1996.

5. Патент 2076726 (RU). Способ лечения псориаза / А.И. Суханов. 1997.

6. Михайлова Е.А., Щербакова Т.П., Шубаков А.А. Изучение эффективности применения препаратов пектиновых полисахаридов на разнотравье в условиях полевого опыта // Научные достижения биологии, химии, физики: материалы Междун. заочной науч.-практ. конф. Новосибирск, 2012. 114 с.

7. Shakhmatov E.G., Toukach P.V., Kuznetsov S.P., Makarova E.N. Structural characteristics of water-soluble polysaccharides from Heracleum sosnowskyi Manden // Carbohydr. Polym. 2014. Vol. 102, Pp. 521-528.

8. Shakhmatov E.G., Atukmaev K.V., Makarova E.N. Structural characteristics of pectic polysaccharides and arabinogalactan proteins from Heracleum sosnowskyi Manden // Carbohydr. Polym. 2016. Vol. 136, Pp. 1358-1369.

9. Dubois M., Qilles K.A., Hamilton J.K., Rebers P.A., Smith F. Colorimetric method for determination of sugars and related substances // Analyt. Chem. Vol. 28. Pp. 350-356.

10. Usov A.I., Bilan M.I., Klochkova N.G. Polysaccharide ciomposition of several calcareous red algae: Isolation of alginate from corallina pilutitara // Bot. Marina. 1995. Vol. 38. Pp. 43-51.

11. Bradford H.M. A rapid and sensitive method for the quantification of microgram quantities of protein utilizing the principal of protein-dye-binding // Anal. Biochem. 1976. Vol. 72, Pp. 248-254.

12. York W.S., Darvill A.G., McNeil M.A., Stevenson T.T., Albercheim P. Isolation and characterization of plant cell walls and cell-wall components // Methods Enzymol. 1985. Vol. 118. Pp. 3-40.

13. Дудкин М.С., Громов В.С., Ведерников Н.А., Каткевич Р.Г., Черно Н.К. Гемицеллюлозы. Рига, 1991. 488 с.

14. Ebringerova A., Hromadkova Z., Heinze T. Hemicellulose // Adv. Polym. Sci. 2005. Vol. 186, Pp 1-67.

15. Doering, A., Lathe, R., Persson, S. An update on xylan synthesis // Mole. Plant. 2012. Vol. 5. Pp. 769-771.

16. Prabasari I., Pettolino F., Liao M.-L., Bacic A. Pectic polysaccharides from mature orange (Citrus sinensis) fruit albedo cell walls: Sequential extraction and chemical characterization // Carbohydr. Polym. 2011. Vol. 84. Pp. 484-494.

17. Zablackis E., Huang J., Muller B., Darvill A.G., Albersheim P. Characterization of the cell-wall polysaccharides of Arabidopsis thaliana leaves // Plant Physiol. 1995. Vol. 107. Pp. 1129-1138.

18. Шахматов Е.Г., Макарова Е.Н., Михайлова Е.А., Шубаков А.А, Оводов Ю.С. Общая химическая характеристика полисахаридов плодов граната (Punica granatum L.) // Бутлеровские сообщения. 2013. T. 33, №3. С. 116-121.

19. Shakhmatov E. G., Toukach P. V., Michailowa E. A., Makarova E. N. Structural studies of arabinan-rich pectic polysaccharides from Abies sibirica L. Biological activity of pectins of A. Sibirica // Carbohydr. Polym. 2014. Vol. 113. Pp. 515-524.

Поступило в редакциию 28 октября 2015 г. 
Shakhmatov E.G. ${ }^{l}$, Mikhailova E.A. ${ }^{2}$, Makarova E.N. ${ }^{1 *}$ STRUCTURAL-CHEMICAL CHARACTERISTIC AND BIOLOGICAL ACTIVITY OF POLYSACCHARIDES FROM HERACLEUM SOSNOWSKYI MANDEN

${ }^{I}$ Institute of Chemistry, Komi Scientific Center of UB RAS, Pervomaiskaia st., 48, Syktyvkar, 167982, Komi Republic

(Russia),e-mail: makarowa.elena-ma@ya.ru

${ }^{2}$ Institute of Physiology, Komi Scientific Center of UB RAS, Pervomaiskaia st., 50, Syktyvkar, 167982, Komi Republic

(Russia)

Was studied character of the changes yield and the monosaccharide composition the arabinogalactan proteins (AGP), pectic polysaccharides and of cross-linking glycans, were isolated from the aboveground part of Heracleum sosnowskyi Manden the sequential treatment with water, $\mathrm{HCl}$ solution, and $\left(\mathrm{NH}_{4}\right)_{2} \mathrm{C}_{2} \mathrm{O}_{4}, \mathrm{KOH}$ and $\mathrm{NaOH}$ solution. The fractions were isolated extraction with water consist mainly of AGP and minor amounts of pectic polysaccharides. The fractions were isolated extraction with aqueous $\mathrm{HCl}$ solution are a mixture of $\mathrm{AGP}$ and pectic polysaccharides, the latter prevailing. The fractions were isolated extraction with aqueous $\left(\mathrm{NH}_{4}\right)_{2} \mathrm{C}_{2} \mathrm{O}_{4}$ are characterized by the predominance of pectic polysaccharides and a minor amount of AGP.

When studying the monosaccharide composition of the fractions extracted $\mathrm{KOH}$ solution determined that the main components of their carbohydrate chains are residues of xylose, glucose and uronic acids that probably specifies the affiliations these fractions of cross-linking glycans class glucuronoarabinoxylans and xyloglucans. The major components of the carbon chain fractions extracted aqueous solution of $\mathrm{NaOH}$, are of mannose and glucose residues, which probably specifies the affiliations these fractions of cross-linking glycans class glucomannan. The last two fractions also contained some amount of pectin polysaccharides.

It is shown high biological activity pectic polysaccharides, from the aboveground part of Heracleum sosnowskyi Manden, extraction $\left(\mathrm{NH}_{4}\right)_{2} \mathrm{C}_{2} \mathrm{O}_{4}$ solution on germination and growth rate of seeds, germs and roots of Triticum aestivum L.

Keywords: Heracleum sosnowskyi, pectin, arabinogalactan protein; structure; biological activity of polysaccharides.

\section{References}

1. Medvedeva E.N., Babkin V.A., Ostroukhova L.A. Khimiia rastitel'nogo syr'ia, 2003, no. 1, pp. 27-27. (in Russ.).

2. Kumar, S., Gupta, P., Sharma, S., Kumar, D. J. of Chin. Integrative Medicine, 2011, vol. 9, pp. 117-128.

3. Senejoux, F., Demougeot, C., Cuciureanu, M., Miron, A., Cuciureanu, R., Berthelot, A., et al. J. Ethnopharmacol., 2013, vol. 147, pp. 536-539.

4. Patent 2057541 (RU). 1996. (in Russ.).

5. Patent 2076726 (RU). 1997. (in Russ.).

6. Mikhailova E.A., Shcherbakova T.P., Shubakov A.A. Nauchnye dostizheniia biologii, khimii, fiziki: materialy Mezhdun. zaochnoi nauch.-prakt. konf. [Scientific achievements of biology, chemistry, physics, materials of the international correspondence scientific-practical conference]. Novosibirsk, 2012, 114 p. (in Russ.).

7. Shakhmatov E.G., Toukach P.V., Kuznetsov S.P., Makarova E.N. Carbohydr. Polym., 2014, vol. 102, pp. 521-528.

8. Shakhmatov E.G., Atukmaev K.V., Makarova E.N. Carbohydr. Polym., 2016, vol. 136, pp. 1358-1369.

9. Dubois M., Qilles K.A., Hamilton J.K., Rebers P.A., Smith F. Analyt. Chem., vol. 28, pp. 350-356.

10. Usov A.I., Bilan M.I., Klochkova N.G. Bot. Marina, 1995, vol. 38, pp. 43-51.

11. Bradford H.M. Anal. Biochem., 1976, vol. 72, pp. 248-254.

12. York W.S., Darvill A.G., McNeil M.A., Stevenson T.T., Albercheim P. Methods Enzymol., 1985, vol. 118, pp. 3-40.

13. Dudkin M.S., Gromov V.S., Vedernikov N.A., Katkevich R.G., Cherno N.K. Gemitselliulozy. [Hemicellulose]. Riga, 1991, 488 p. (in Russ.).

14. Ebringerova A., Hromadkova Z., Heinze T. Adv. Polym. Sci. 2005, vol. 186, pp 1-67.

15. Doering, A., Lathe, R., Persson, S. Mole. Plant., 2012, vol. 5, pp. 769-771.

16. Prabasari I., Pettolino F., Liao M.-L., Bacic A. Carbohydr. Polym., 2011, vol. 84, pp. 484-494.

17. Zablackis E., Huang J., Muller B., Darvill A.G., Albersheim P. Plant Physiol., 1995, vol. 107, pp. 1129-1138.

18. Shakhmatov E.G., Makarova E.N., Mikhailova E.A., Shubakov A.A, Ovodov Iu.S. Butlerovskie soobshcheniia, 2013 , vol. 33, no. 3, pp. 116-121. (in Russ.).

19. Shakhmatov E.G., Toukach P.V., Michailowa E.A., Makarova E.N. Carbohydr. Polym., 2014, vol. 113, pp. 515-524.

Received October 28, 2015

Revised November 5, 2015

\footnotetext{
${ }^{*}$ Corresponding author.
} 